\title{
Learners' Perceptions of Online Exams: A Comparative Study in Turkey and Kyrgyzstan
}

Gülgün Afacan Adanır ${ }^{1}$, Rita İsmailova², Asan Omuraliev ${ }^{3}$, and Gulshat Muhametjanova ${ }^{3}$

${ }^{1}$ Distance Education Center, Ankara University, Ankara, Turkey, ${ }^{2}$ Department of Computer Engineering, Kyrgyz-Turkish Manas University, Bishkek, Kyrgyz Republic, ${ }^{3}$ Department of Applied Mathematics and Informatics, Faculty of Sciences, Kyrgyz-Turkish Manas University, Bishkek, Kyrgyz Republic

\begin{abstract}
As online learning is becoming very popular in formal educational settings and in individual development, online exams are starting to be recognized as one of the more efficient assessment methods. Online exams are effective in either blended or traditional forms of learning, and, when appropriately used, bring benefits to both learners and the learning process. However, learners' perceptions of online exams in developing countries have not been widely studied despite the potential of such research for contributing to more effective use of online exams in these countries. Thus, this study served two purposes. First, it aimed to investigate students' perceptions of online exams at a state university in Turkey, and at a state university in Kyrgyzstan. Second, the study compared the results. Structured as a mixed study, the research was conducted during the 2018-2019 fall term. The participants were 370 undergraduate students taking first-year courses online. Quantitative data considered learners' perception scores gathered via a survey, whereas qualitative data considered learners' opinions in response to an open-ended question. According to the quantitative analysis, learners' perceptions differed according to gender, major, and prior online course experience variables. In addition, Turkish and Kyrgyz learners differed in that Turkish learners found online exams less stressful and more reliable and fairer than traditional paper-based exams when compared with their Kyrgyz counterparts. The qualitative analysis provided important results for future planning in both institutions.
\end{abstract}

Keywords: online exam, online learner, perception, comparative study, developing country 


\section{Introduction}

As a form of assessment, evaluation, and feedback, online exams play an important role in online learning. Advances have led to the increasing use of information and communication technologies (ICT) to conduct online exams in universities worldwide. The Internet and ICT provide such useful solutions in the education field that online exams have even come to be understood as one method of course evaluation (Al-Mashaqbeh \& Al Hamad, 2010). Online exams are effective for diagnostic, formative, and summative assessments and provide students with the opportunity of demonstrating performance (Laine, Sipilä, Anderson, \& Sydänheimo, 2016).

While traditional exams, using paper and pens, result in a heavy burden for learners and instructors, online exams provide solutions for such issues (Sarrayrih \& Ilyas, 2013). Instructors can save time in grading and mark compilation, resulting in lower administrative costs, while students can receive immediate and detailed feedback, take their exams at a time and in a place that works best for them (Angus \& Watson, 2009), and access self-assessment opportunities (Sorensen, 2013). However, online exams present several challenges, including increased work in the preparation stage, the possibility of technical failures, security issues, and dealing with cheating (Alsadoon, 2017). The extra work refers to the additional time needed to create question banks for online exams. However, the reusability of questions in different exams turns this drawback into an advantage. As for the other challenges, researchers have been working for several years to find appropriate solutions.

As online exams become an important assessment method in online learning, it is essential to analyze learners' perceptions (Dermo, 2009). This is especially true in developing countries where universities have only recently initiated the use of online exams in courses with large numbers of students. Also, some institutions of the countries started to employ online exams countrywide. For instance, driving license, foreign language, certification, promotion, and recruitment exams have been conducted in online means (Adanır, Akmatbekova, \& Muhametjanova, 2020). While some developed countries have had more experience and success related to the implementation of online exams, learners in developing countries face many challenges due to limited access to ICT, lack of experience in online education or having a lower computer literacy level. Therefore, it is necessary to measure the readiness of such learners to accept online methods in the assessment of knowledge. In addition, the investigation of learners' perceptions could reveal factors that would make online examinations more accurate and effective.

Although there have been studies that investigated learners' perceptions of online exams, there has not yet been such a study comparing the perceptions of learners from different countries. Building on the work of Liu, Liu, Lee, and Magjuka (2010) who suggested that cultural differences could affect perception, this study investigated and compared online exam perceptions of students in the state university in Turkey with students in the state university in the Kyrgyz Republic.

In both universities, distance education centres manage online learning courses and programs. In the state university of Turkey, the centre is AUDCE, while in Kyrgyzstan, it's named the KTMUDCE.

AUDCE was founded in 2002. Since 2015, AUDCE has been providing online exams for evaluation of practical tasks as well as midterm assessment of learners in the state university of Turkey. In Kyrgyz University, the KTMUDCE was started in 2013. However, Kyrgyz students currently do not take online exams other than in one compulsory informatics course, offered to first-year students of all bachelor's 
degree programs. Taking into account this difference, this study analyzed and compared students' perceptions of knowledge evaluation.

This paper first reviews the literature, and then describes the methodology for the study including the research design and questions. Next, the findings are presented and discussed. Finally, the paper concludes with recommendations for action and further study.

\section{Literature Review}

Improving learners' qualifications is highly important in the educational context. Such improvement can be supported by assessment, evaluation, and feedback activities (Yllmaz, 2016). Assessment, an essential component of education, has both summative and formative types. Summative assessment aims to gather, describe, and quantify information related to student performance, while formative assessment aims to improve teaching and learning (Baleni, 2015). Online learning can benefit greatly from various assessment methods since there is a lack of face-to-face contact between students and instructors that might otherwise provide useful information about course content and delivery (Timms, 2017). In addition, to promote successful online learning experiences, learners' progress should be monitored in order to provide appropriate feedback and grading of performance. The traditional assessment methods such as online exams involving multiple-choice or true-false types of questions are useful for acquiring basic information about learning in a given course. On the other hand, authentic assessment methods such as online discussions, assignments, projects, presentations, and journals are effective for a deeper assessment of learner performance (Gülbahar, 2017). Authentic assessment methods are generally appropriate for courses with a small number of students since they require additional time for grading.

Thanks to improvements in ICT, learners and instructors witnessed more applications of online courses and thus, online exams (Kirtman, 2009). Although there is no restriction on their use, online exams are especially appropriate for courses conducted online and having a high number of students. At the same time, online exams bring advantages such as test security, safe data storage, immediate exam results, cost-effectiveness, saving paper and time, and automated record-keeping for learners, instructors, and institutions (Ilgaz \& Adanır, 2020).

One emergent area in the research is learner perception. Many studies have analyzed learners' online exam experiences and perceptions. Cabı (2016) investigated master's students' perceptions of various e-assessment methods. The results showed that students preferred e-exams because they offered immediate feedback, motivation for study, and self-assessment. Yet, students had concerns related to cheating possibilities, technical failures, and the limited number of sessions for online exams offered throughout the term. The work of Laine et al. (2016) found that students were satisfied with both the electronic versions of exams and the appropriateness of exam questions. Their only challenge related to mathematical problems and calculations, in which they indicated the difficulties entering mathematical calculations and unpleasant use of the calculator. Böhmer, Feldmann, and Ibsen (2018) investigated part-time engineering students' opinions about the e-exam system and found that they were generally satisfied since they could easily take e-exams and receive their grades quickly.

In considering the preconceptions of learners toward online exams, Hillier (2014) surveyed undergraduate students. According to the findings, learners generally had positive attitudes toward 
online exams. However, they indicated concerns that this approach would favour students from technology majors over those from other departments. The students surveyed felt that students in computer departments would more easily adapt to online exams since they had more typing experience. Other concerns included the risk of technical failure and the possibility of cheating. Research in the UAE by Elmehdi and Ibrahem (2019) showed that students felt positively about online exams due to facilitated logistics and improved learning. Moreover, researchers reported no difference in perception in terms of age and gender.

The literature review demonstrated that learners had generally positive attitudes toward online exams. However, differences according to demographic variables were less clear. In addition, the review revealed that the concerns of learners in developed countries were also being reported by learners in developing countries. In general, these concerns include the possibility of cheating, risk of technical failures, lack of exam time, and lack of quality of questions.

Although not usually available or widely used in developing countries, some researchers have proposed recent technologies to improve system infrastructure in order to eliminate problems and user concerns. For example, Bawarith, Basuhail, Fattouh, and Gamalel-Din (2017) implemented an e-exam management system, which aims to detect and prevent cheating in online exams with the help of a fingerprint reader authenticator and the use of an Eye Tribe tracker in exam sessions. As another example, Kolhar, Alameen, and Gharsseldien (2018) proposed an Online Lab Examination Management System (OLEMS) in order to prevent misconduct and to secure the process of lab examination.

Other researchers have offered more appropriate frameworks and control procedures. For example, D'Souza and Siegfeldt (2017) developed a conceptual framework to identify cheating in online and takehome exams. Cluskey, Ehlen, and Raiborn (2011) proposed Online Exam Control Procedures for the security of online exams. In the first procedure, they proposed exams be set at one time, with access to exam questions only through a specified browser to guarantee that learners would be locked into the exam page and prevented from exiting/returning, cutting/pasting or otherwise manipulating the system. Backman (2019) also recommended using software that prevents Internet access and preparing a question bank so that students were asked different questions. The same research (i.e., Backman, 2019) also proposed to ask more demanding questions, limiting time to answer them to prevent cheating.

Despite a wide variety of research, the review of literature revealed that there is not prior work comparing the perceptions of learners from different countries. This study therefore is the first that investigates undergraduate learners' perceptions in two developing countries (i.e., Turkey and Kyrgyzstan) and compares the results in order to identify similarities and differences in perceptions.

\section{Methodology}

\section{Research Questions}

Online exam perception can depend on many factors including students' educational backgrounds, computer literacy, and the ICT level of the country they live in. Research that probes these and other 
factors and analyzes the differences across countries could help shed light on measures that will support the more effective use of online exams. Thus, this study identified four research questions:

1. What are the perceptions of learners towards online exams at the state university of Turkey?

2. What are the perceptions of learners towards online exams at the state university of Kyrgyzstan?

3. Is there any difference between Turkish learners and Kyrgyz learners according to their perceptions of online exams?

4. What are the opinions of learners towards online exams?

\section{Research Design and Participants}

The study was conducted during the 2018-2019 fall term and structured as a mixed study. Quantitative data consider learners' perception scores gathered via the survey, whereas qualitative data consider learners' opinions towards online exams. The mixed study approach was found useful in the analysis of two different data types (i.e., quantitative and qualitative), and strengthened research results.

The participants of the study were undergraduate students from a state university in Turkey and a state university in Kyrgyzstan taking first-year compulsory courses online. They were selected since they are all in the same grade level, taking online compulsory courses, and having a similar level of online exam experience. While the learners in Turkey would have had experience with online midterm exams in their Foreign Language and Informatics courses, the learners in Kyrgyzstan would have had experience due to a compulsory Informatics course.

There were approximately 8,400 students in Turkey's university and 1,200 in Kyrgyzstan's, all at the first-year level. The link to the online questionnaire, created for the study, was e-mailed to them from both universities. In total, 370 students responded to the survey. The demographic characteristics of the participants are shown in Table 1. 
Table 1

Analysis of Demographic Data of Participants

\begin{tabular}{|c|c|c|c|c|c|}
\hline \multirow{2}{*}{$\begin{array}{l}\text { Demographic } \\
\text { characteristic }\end{array}$} & \multirow{2}{*}{ Variables } & \multicolumn{2}{|c|}{ Turkish } & \multicolumn{2}{|c|}{ Kyrgyz } \\
\hline & & Frequency $(f)$ & Percentage (\%) & Frequency $(f)$ & Percentage (\%) \\
\hline \multirow[t]{2}{*}{ Gender } & Female & 108 & 58.4 & 111 & 60.0 \\
\hline & Male & 77 & 41.6 & 74 & 40.0 \\
\hline Total & & 185 & 100 & 185 & 100 \\
\hline \multirow[t]{4}{*}{ Age } & $17-25$ & 171 & 92.4 & 184 & 99.5 \\
\hline & $26-34$ & 11 & $5 \cdot 9$ & 0 & O \\
\hline & $35-43$ & 1 & 0.5 & 1 & 0.5 \\
\hline & $44+$ & 2 & 1.1 & O & O \\
\hline Total & & 185 & 100 & 185 & 100 \\
\hline \multirow{6}{*}{$\begin{array}{l}\text { Number of } \\
\text { online courses } \\
\text { taken before }\end{array}$} & $\mathrm{O}$ & 82 & $44 \cdot 3$ & 22 & 11.9 \\
\hline & 1 & 14 & $7 \cdot 6$ & 24 & $13 \cdot 0$ \\
\hline & 2 & 39 & 21.1 & 40 & 21.6 \\
\hline & 3 & 27 & 14.6 & 26 & 14.1 \\
\hline & 4 & 9 & 4.9 & 22 & 11.9 \\
\hline & 5 & 14 & 7.6 & 51 & 27.6 \\
\hline Total & & 185 & 100 & 185 & 100 \\
\hline
\end{tabular}

In the scope of the survey, there were students representing six different faculties including Applied Science, Social Science, Education, Engineering, Medicine, and Religion. Learners' distribution by faculty is provided in Table 2 .

The most notable difference in distribution by faculty was in the field of applied science: among participants from Turkey, $5.9 \%$ were in this faculty, while among Kyrgyz respondents, it was $28.6 \%$. In addition, unlike the Turkish sample group, there were no students from the medicine and religion departments among the Kyrgyz participants. 
Table 2

Percentage of Students by Faculty

Percentage (\%)

\begin{tabular}{|c|c|c|c|}
\hline & & Turkish & Kyrgyz \\
\hline \multirow[t]{7}{*}{ Faculty } & Applied Science & $5 \cdot 9$ & 28.6 \\
\hline & Social Science & $25 \cdot 4$ & 29.7 \\
\hline & Education & 14.1 & 11.4 \\
\hline & Engineering & 31.4 & 30.3 \\
\hline & Medicine & $15 \cdot 7$ & $\mathrm{O}$ \\
\hline & Religion & 7.6 & $\mathrm{O}$ \\
\hline & Total & 100 & 100 \\
\hline
\end{tabular}

\section{Data Collection Tool and Analysis}

The study used a scale, based on the work of Hillier (2014), consisting of items and rankings. The scale covered eight major themes: (a) affective factors, (b) teaching and learning, (c) validity, (d) reliability, (e) practicality, (f) security, (g) production, and (h) adoption. The scale was designed to work with 5point Likert-type responses, which included rankings ranging from strongly disagree to strongly agree. In this study, the production theme, focusing on essay questions and handwriting, was not included since it is not relevant to the format of online exams that use only multiple-choice questions. The resulting scale covered 15 items. Participants provided responses voluntarily, therefore, reliability analysis was performed based on 370 participants, and the resulting Cronbach Alpha value was estimated at 0.82 . In addition to the survey questions, thoughts of learners were gathered through an open-ended question asking their opinions toward online exams.

To analyze quantitative data collected through the scale, appropriate statistical analyses (i.e., $t$-test and ANOVA test) were used. The responses of learners from the two universities were compared using the $t$-test. All tests were conducted using SPSS 20.0 software. For analysis of the open-ended question, however, the content analysis approach was employed. In total, 32 participants (i.e., 18 Turkish and 14 Kyrgyz) responded to the open-ended question. In this study, open coding as offered by Strauss and Corbin (1990) was used and an inter-coder agreement strategy was applied for reliability. The coefficient was 0.72 , which is considered to be within an acceptable range as proposed by Krippendorff (2004).

\section{Results and Discussion}

\section{Research Question 1: What are the Perceptions of Learners Towards Online Exams at the State University of Turkey?}

Relationship between Turkish learners' gender and perceptions of online exams. An independent sample $t$-test was performed to examine whether there was a difference between male 
and female learners' perceptions toward online exams at the state university of Turkey. Results, provided in Table 3, show a statistically significant difference between male and female learners in terms of four of the 15 perceptions the respondents were asked to rank.

Table 3

Results of the Independent Samples T-test on Turkish Learners' Perception by Gender

\begin{tabular}{lcccc}
\hline & $t$ & $d f$ & Sig. (2-tailed) & Mean difference \\
\hline $\begin{array}{l}\text { 1. Using a computer for an exam is more } \\
\text { stressful than a handwritten paper } \\
\text { exam }\end{array}$ & -3.269 & 183 & .001 & -.662 \\
$\begin{array}{l}\text { 9. Online exams favour some students } \\
\text { more than others }\end{array}$ & 2.144 & 183 & .033 & .374 \\
$\begin{array}{l}\text { 14. It is easier to cheat in online exams } \\
\text { than with paper-based exams }\end{array}$ & -2.470 & 183 & .014 & -.504 \\
$\begin{array}{l}\text { 15. I want online exams to replace } \\
\text { paper-based exams in the context of } \\
\text { online courses }\end{array}$ & 2.539 & 183 & .012 & .497 \\
\hline
\end{tabular}

According to results, female learners tend to be more stressed than male learners (item 1), while more male learners would prefer that online exams replace paper-based exams in the context of online courses (item 15). Regarding the possibility of cheating on online exams, female learners expressed more concern than males (item 14). The high stress and cheating concerns of female learners may be related. However, more male learners perceived that online exams favoured some students over others.

Relationship between Turkish learners' academic major and perceptions of online exams. The relationship between learners' academic major and perceptions of online exams was analyzed. The ANOVA test revealed a statistically significant difference between learners' academic major and perceptions of online exams for three items as shown in Table 4.

Learners from the Applied Science and Engineering faculties perceived online exams as reliable and secure while learners from Social Science, Medicine, and Religion perceived them as less reliable than paper-based exams. Furthermore, Social Science, Medicine, and Religion faculty learners perceived that it is easier to cheat in online exams than with paper-based exams as compared with Engineering and Applied Science students. 
Table 4

Results of the One-Way ANOVA Test on Turkish Learners' Perception by Academic Major

\begin{tabular}{|c|c|c|c|c|c|c|}
\hline \multirow{4}{*}{$\begin{array}{l}\text { 8. The technology } \\
\text { used in online } \\
\text { exams is unreliable }\end{array}$} & \multirow{4}{*}{$\begin{array}{l}\text { Between Groups }{ }^{\mathrm{a}} \\
\text { Within Groups } \\
\text { Total }\end{array}$} & \multirow{2}{*}{$\frac{\text { Sum of squares }}{17.733}$} & \multirow{2}{*}{$\frac{d f}{5}$} & \multirow{2}{*}{$\begin{array}{c}\text { Mean square } \\
3.547\end{array}$} & \multirow{2}{*}{$\frac{F}{2.340}$} & \multirow{2}{*}{$\begin{array}{l}\text { Sig. } \\
.044\end{array}$} \\
\hline & & & & & & \\
\hline & & 271.326 & 179 & 1.516 & & \\
\hline & & 289.059 & 184 & & & \\
\hline 13. Online exams & Between Groups & 20.764 & 5 & 4.153 & 2.523 & .031 \\
\hline $\begin{array}{l}\text { are just as secure } \\
\text { as paper-based }\end{array}$ & Within Groups & 294.641 & 179 & 1.646 & & \\
\hline exams & & 315.405 & 184 & & & \\
\hline 14. It is easier to & Between Groups & 39.293 & 5 & 7.859 & 4.473 & .001 \\
\hline cheat in online & Within Groups & 314.469 & 179 & 1.757 & & \\
\hline exams than with & Total & & & & & \\
\hline paper-based exams & & 353.762 & 184 & & & \\
\hline
\end{tabular}

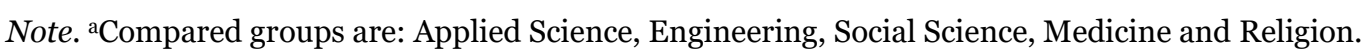

Relationship between the number of online courses taken and perceptions of online exams. Since experience can change an individual's perception, the impact of the number of online courses taken on the perception of online exams was analyzed. Regarding Turkish learners, no statistically significant difference was found between perceptions of online exams and the number of online courses taken. That is, prior experience had no effect on their perceptions of online exams.

\section{Research Question 2: What are the Perceptions of Learners Towards Online Exams at the State University of Kyrgyzstan?}

Relationship between Kyrgyz learners' gender and perceptions of online exams. An independent sample $t$-test was performed to see whether there was a difference between Kyrgyz male and female learners' perceptions toward online exams.

As shown in Table 5, the results of the $t$-test showed a statistically significant difference between male and female learners in two items. Female learners taking online exams felt more disadvantaged than male learners, with the mean difference being -.365 (item 2), while male learners perceived that it was easier to cheat in online exams than with paper-based exams, with a mean difference of .468 (item 14).

Table 5

Results of the Independent Samples T-test on Kyrgyz Learners' Perception by Gender

\begin{tabular}{|c|c|c|c|c|}
\hline & $t$ & $d f$ & Sig. (2-tailed) & Mean difference \\
\hline $\begin{array}{l}\text { 2. I am at a disadvantage when } \\
\text { undertaking online exams }\end{array}$ & -1.986 & 183 & .049 & -.365 \\
\hline $\begin{array}{l}\text { 14. It is easier to cheat in online exams } \\
\text { than with paper-based exams }\end{array}$ & 2.412 & 183 & .017 & .468. \\
\hline
\end{tabular}


Relationship between Kyrgyz learners' academic major and perceptions of online exams. To determine the relationship between learners' academic major and perceptions of online exams, the ANOVA test was used. Results (Table 6) showed a statistically significant difference between learners' academic major and perception of online exams only for item 13. That is, learners from the Engineering faculty perceived online exams to be just as secure as paper-based exams while learners from the Education faculty perceived them as less secure than paper-based exams.

Table 6

Results of the One-Way ANOVA Test on Kyrgyz Learners' Perceptions by Academic Major

\begin{tabular}{llccccc}
\hline & Sum of squares & $d f$ & Mean square & $F$ & Sig. \\
\hline 13. Online exams & Between Groups $^{\mathrm{a}}$ & 14.713 & 3 & 4.904 & 3.294 & .022 \\
are just as secure as & Within Groups & 269.471 & 181 & 1.489 & & \\
paper-based exams & Total & 284.184 & 184 & & & \\
& & & & & & \\
\hline
\end{tabular}

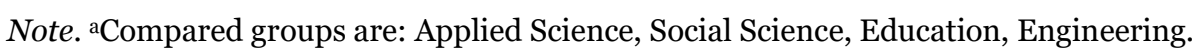

Relationship between the number of online courses taken and perceptions of online exams. Results of the ANOVA test showed a statistically significant difference between the number of online courses taken and students' perceptions of online exams for items 4 and 6 (Table 7). That is, learners who had taken more than three courses thought that the potential for immediate feedback with an online exam would help improve their learning in comparison with those who took only one course. However, more experience resulted in a less positive estimation of suitability: more of the learners who took two courses thought that online exams were appropriate for their discipline/subject area than the learners who took five courses.

Table 7

Relationship between the Number of Online Course Taken and Perceptions of Online Exams

\begin{tabular}{|c|c|c|c|c|c|c|}
\hline & & Sum of squares & $d f$ & Mean square & $F$ & Sig. \\
\hline $\begin{array}{l}\text { 4. The potential } \\
\text { for immediate }\end{array}$ & $\begin{array}{l}\text { Between } \\
\text { Groups }\end{array}$ & 17.074 & 5 & 3.415 & 2.730 & .021 \\
\hline $\begin{array}{l}\text { feedback with an } \\
\text { online exam }\end{array}$ & $\begin{array}{l}\text { Within Groups } \\
\text { Total }\end{array}$ & 222.643 & 178 & 1.251 & & \\
\hline $\begin{array}{l}\text { could help } \\
\text { improve my } \\
\text { learning }\end{array}$ & & 239.717 & 183 & & & \\
\hline $\begin{array}{l}\text { 6. Online exams } \\
\text { are appropriate }\end{array}$ & $\begin{array}{l}\text { Between } \\
\text { Groups }\end{array}$ & 21.285 & 5 & 4.257 & 2.619 & .026 \\
\hline for my & Within Groups & 289.318 & 178 & 1.625 & & \\
\hline $\begin{array}{l}\text { discipline/subject } \\
\text { area }\end{array}$ & lotal & 310.603 & 183 & & & \\
\hline
\end{tabular}

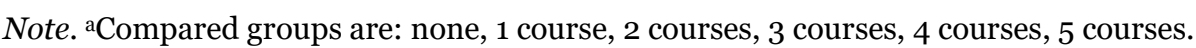




\section{Research Question 3: Is There any Difference Between Turkish Learners and Kyrgyz Learners According to Their Perceptions of Online Exams?}

An independent sample $t$-test was performed to see whether there was a difference between Turkish and Kyrgyz learners' perceptions toward online exams.

The results of the $t$-test showed a statistically significant difference between the perception of learners from Turkey and Kyrgyzstan in 12 of the 15 items (Table 8). Turkish learners appreciated the capabilities of online exams more than Kyrgyz learners did. Specifically, Turkish learners indicated that online exams are consistent with learning approaches, provide immediate feedback, are appropriate for demonstrating knowledge, and appropriate for the chosen major. Moreover, Turkish learners demonstrated more expectation towards the online exams in place of paper-based exams as they want online exams to replace paper-based exams in the context of online courses (item 15). On the other hand, they also stated concerns about technical problems, cheating possibilities, and the impracticality of using the campus computer lab to take exams.

Table 8

Results of the Independent Samples T-test on Learners' Perception by Country

\begin{tabular}{lcccc}
\hline & $T$ & $d f$ & $\begin{array}{c}\text { Sig. (2- } \\
\text { tailed) }\end{array}$ & $\begin{array}{c}\text { Mean } \\
\text { difference }\end{array}$ \\
\hline $\begin{array}{l}\text { 1. Using a computer for an exam is more } \\
\text { stressful than a handwritten paper exam }\end{array}$ & 1.276 & 368 & .203 & .1784 \\
$\begin{array}{l}\text { 3. Online exams are consistent with } \\
\text { contemporary learning approaches at university }\end{array}$ & -4.225 & 368 & .000 & -.5351 \\
$\begin{array}{l}\text { 4. The potential for immediate feedback with an } \\
\text { online exam could help improve my learning }\end{array}$ & -6.058 & 368 & .000 & -.7081 \\
$\begin{array}{l}\text { 5. Online exams allow me to demonstrate my } \\
\text { knowledge in more ways than paper-based } \\
\text { exams }\end{array}$ & -4.953 & 368 & .000 & -.6162 \\
$\begin{array}{l}\text { 6. Online exams are appropriate for my } \\
\text { discipline/subject area }\end{array}$ & -4.871 & 368 & .000 & -.6541 \\
$\begin{array}{l}\text { 7. Online exams need to include a variety of } \\
\text { question types to test my knowledge fully }\end{array}$ & 3.458 & 368 & .001 & .4324 \\
$\begin{array}{l}\text { 8. The technology used in online exams is } \\
\text { unreliable }\end{array}$ & 3.835 & 368 & .000 & .4919 \\
$\begin{array}{l}\text { 10. Paper-based exams are fairer than online } \\
\text { exams }\end{array}$ & 2.591 & 368 & .010 & .3568 \\
$\begin{array}{l}\text { 11. Technical problems make doing exams via } \\
\text { computer impractical }\end{array}$ & -5.988 & 368 & .000 & -.7189 \\
$\begin{array}{l}\text { 12. Doing exams in the campus computer labs is } \\
\text { impractical }\end{array}$ & -5.993 & 368 & .000 & -.7892 \\
$\begin{array}{l}\text { 14. It is easier to cheat in online exams than } \\
\text { with paper-based exams }\end{array}$ & -4.623 & 368 & .000 & -.6486 \\
$\begin{array}{l}\text { 15. I want online exams to replace paper-based } \\
\text { exams in the context of online courses }\end{array}$ & -3.416 & 368 & .001 & -.4703 \\
\hline
\end{tabular}

According to results, Turkish learners agree more strongly with all stated items except items 1, 7, 8, and 10. The results related to item 1 demonstrated that a higher number of Kyrgyz learners found online exams to be more stressful than paper-based exams when compared to the number of Turkish learners 
who reported the same thing. The results related to item 7 showed that more Kyrgyz learners than Turkish learners perceived that the inclusion of various question types would test their knowledge more fully. Furthermore, Kyrgyz learners, when compared to Turkish learners, showed more apprehension as they specifically highlighted those items that typically raise anxiety levels: they thought that "technology used in online exams is unreliable" (item 8), and that "paper-based exams are fairer than online exams" (item 10). This might be explained by the fact that, in the Kyrgyz university, all exams are mostly paper-based and the General Course exams are all paper-based. The only experience of online exams is related to the compulsory Informatics course. This might explain Kyrgyz students' perceptions of online exams as unreliable, and not as fair as paper-based ones.

\section{Research Question 4: What are the Opinions of Learners Towards Online Exams?}

In the open-ended question part of the survey, the majority of Turkish participants indicated that online exams were effective and practical, and hence, they supported their continuation and even expansion. In Turkey, legal restrictions prevent the implementation of final exams in an online format; the presence of proctors is required. Thus, only midterm exams can be held online. Nevertheless, a transition to online final exams, in a format analogous to midterm exams, was supported by some participants. For instance, one Turkish learner indicated that:

I found online courses beneficial and useful. In my opinion, both midterm and final exams of these courses should be conducted online in the schools and under the control of proctors. In this way, cheating issues can be eliminated.

Using the physical space of universities' computer laboratories for final exams could provide opportunities for carrying out such exams both online and under proctor control.

Cheating was a major concern of many participants. However, there was some misunderstanding about the meaning of cheating in the context of online exams. One participant stated, "The students have a helping attitude toward each other, and exam questions are generally solved by a group of learners." Another said, "I did not have previous knowledge about the cheating issue for online exams. Sorry since I solved the exam questions with my friends."

Although participants from Kyrgyzstan had little prior experience in taking online exams, they had several concerns which may have originated from existing problems. One concern was the existence of identical questions in exams across terms or even years. A Kyrgyz participant stated that, "Online exam questions are the same as the ones provided 3-4 years before." Participants said that some students memorized prior exam questions, forgetting the rest of the course content, leading to superficial learning. In order to prevent this and increase motivation, it is recommended that instructors give learners new and highly distinct questions in exams.

Another concern of learners from Kyrgyzstan was evaluation, due to the fact that online exams have only multiple-choice questions. For instance, one Kyrgyz participant stated that, "The technique of online exams is not appropriate since there are only multiple-choice questions, it is like a practice test." The inclusion of various types of questions adds to the effectiveness of exams, especially at the university level. To enhance the effectiveness of online exams and make the evaluations more useful to students, it is recommended that various types of questions, such as drag and drop, matching, and essay type questions, be considered for inclusion in online exams. In addition, in the final grading, along with 
online exams, it is recommended to also evaluate learners' participation work in other online activities, such as assignment uploads, and forum postings.

\section{Conclusion}

This study explored online exam perceptions of learners in two developing countries and additionally compared perceptions between those two countries. The participants were first-year undergraduate learners from Turkey and Kyrgyzstan. All were in their initial year, and therefore had no prior experience with online exams.

According to the results, online exam perceptions differed in terms of gender: Turkish female learners felt more stressed and Kyrgyz female learners thought they were disadvantaged as compared to males. The same results were observed in the work of Hillier (2014) in which female learners reported more stress and more concerns about technical problems during online exams. However, research conducted in the UAE by Elmehdi and Ibrahem (2019), found no difference in online exam perception in terms of gender. Therefore, further (qualitative) research to define the reasons for this difference in Turkish and Kyrgyz learners should be conducted.

In considering the academic background of students, the differences in perception of online exams that was noted between students from different disciplines was related to security and reliability. In both countries, Engineering learners considered online exams to be as secure as paper-based exams. On the other hand, Turkish learners from the Social Science, Medicine, and Religion departments, and Kyrgyz learners from the Education department perceived online exams to be less secure and reliable. An analysis of the open-ended questions suggests that this difference is due to students' level of computer literacy, which is related to how closely their field of study is connected to computer science. This result is in line with results obtained in a recent study on the perception of online education as a whole undertaken by Ilgaz and Adanır (2020). However, other studies, such as one carried out by Bandele, Oluwatayo, and Omodara in 2015, found that undergraduates' opinions of online exams did not differ in terms of their majors. The factors that result in online exam perception differences based on learners' fields of study could be a topic for future research.

Prior online learning experience also impacted online exam perceptions in different ways for Turkish and Kyrgyz participants. According to results, prior experience did not affect learners' perceptions of online exams in Turkey. On the other hand, Kyrgyz learners taking more than three online courses had positive attitudes toward online exams and reported their potential for improving learning through the provision of immediate feedback. This is similar to the findings of Sorensen (2013) who reported that students felt e-assessment provided immediate feedback and value to their learning, and hence believed it should be more accessible in the context of learning management systems.

Some Turkish students' perceptions toward online exams can be attributed to their concerns about implementation. A major issue was cheating. In a recent study by Cerimagic and Hasan (2019), it was observed that $81 \%$ of learners cheated or attempted to cheat during online exams. However, in the study by Case, King, and Case (2019) it was also observed that students' perceptions suggest it is becoming more difficult to cheat in online exams. This can be due to emergence of more appropriate frameworks and control procedures. For instance, novel technologies that provide online proctoring capabilities could eliminate cheating issues. The responses of participants were in line with the work of Atoum et 
al. (2017), who developed a multimedia analytics system that performs automatic online exam proctoring and detects cheating behaviours. In addition, Backman (2019) recommended steps that instructors could take to reduce the occurrences of cheating. These include the implementation of online exams in a physical room where all exam takers are present, inclusion of more demanding questions, allocation of less time for completing the exam, availability of software preventing Internet access, and selection of random questions.

Another concern of Turkish learners was the lack of time provided for some questions, especially those requiring paper-based calculations. This issue could be eliminated with the allocation of more time for answering such questions. In addition, online calculation tools, such as those as offered by Finnish Matriculation Examination Board (Ylioppilastutkintolautakunta, 2017), could be included in the online exam system. As for the time lost due to technical failures, Turkey's AUDCE offered a solution that could have application in other developing countries. While online exams are taking place, learners have access to an online chat tool that is integrated into the online exam system. When learners report technical failure, the support team from AUDCE examines log records and, where there has been such a failure, provides students with the opportunity to re-take the exam if necessary.

Kyrgyz learners reported concerns related to questions provided in the e-exam system. Their initial concern was the repetition of questions in exams from one term to the next. This situation pushes learners to memorize answers instead of deeply learning the course content. In this respect, it is recommended that universities vary questions more often for better assessment and increased student motivation. In addition, the use of open-ended questions in e-exams may result in a better assessment of students' knowledge. For instance, Benli and İsmailova (2018) proposed a method for the evaluation of exams with open-ended questions. However, the evaluation of such questions by instructors is time demanding, especially when it comes to large classes.

Finally, the results of this study showed countrywide differences in perception of online exams. There can be many reasons for such differences, including ICT infrastructure level, differences in education systems, and cultural differences in both learning and in certain demographic variables such as gender. Determining the reasons for these differences could be the focus of further study.

To conclude, online exams provide students with benefits such as time reduction in view of savings on transportation, ease of access, and the immediate announcement of exam results. However, the ICT environment is one of the major factors influencing students' perceptions. Adding courses that raise the computer literacy rate would increase the knowledge base of learners and thus, improve online exam perception. In addition, the development of system usage tutorials such as in the case of the distance education centre in Turkey could be helpful. Furthermore, in the initial weeks of each semester or before exam sessions, universities could inform learners about the use and security of online exams through guides or face-to-face sessions. Such steps could eliminate some concerns and result in better online exam experiences.

\section{Acknowledgement}

This research was supported by Turkish Council of Higher Education (YOK) under the Mevlana program, project MEV.2018-675. The authors would like to thank IRRODL reviewers and editors for their valuable revisions and contributions. 


\section{References}

Adanır, G.A., Akmatbekova, A., \& Muhametjanova, G. (2020). Longitudinal study of Kyrgyz students' general physics course performance in paper-based versus online-based tests. Education and Information Technologies. doi: 10.1007/s10639-020-10175-7

Al-Mashaqbeh, I.F., \& Al Hamad, A. (2010). Student's perception of an online exam within the decision support system course at $\mathrm{Al}$ al-Bayt university. In Proceedings Second International Conference on Computer Research and Development, ICCRD 2010 (pp. 131-135). doi: 10.1109/ICCRD.2010.15

Alsadoon, H. (2017). Students' perceptions of e-assessment at Saudi electronic university. TOJET: The Turkish Online Journal of Educational Technology, 16(1), 147-153. Retrieved from https://eric.ed.gov/?id=EJ1124924

Angus, S.D., \& Watson, J. (2009). Does regular online testing enhance student learning in the numerical sciences? Robust evidence from a large data set. British Journal of Educational Technology, 4O(2), 255-272. doi: 10.1111/j.1467-8535.2008.00916.x

Atoum, Y., Chen, L., Liu, A.X., Hsu, S.D.H., \& Liu, X. (2017). Automated online exam proctoring. IEEE Transactions on Multimedia, 19(7), 1609-1624. doi: 10.1109/TMM.2017.2656064

Backman, J. (2019). Students' experiences of cheating in the online exam environment (Bachelor's thesis, Rectors' Conference of Finnish Universities of Applied Sciences). Retrieved from https://www.theseus.fi/bitstream/handle/10024/167963/Thesis.pdf?sequence=2\&isAllowed $=\mathrm{y}$

Baleni, Z.G. (2015). Online formative assessment in higher education: Its pros and cons. Electronic Journal of e-Learning, 13(4), 228-236. Retrieved from https://www.learntechlib.org/p/160781/

Bandele, S.O., Oluwatayo, J.A., \& Omodara, M.F. (2015). Opinions of undergraduates on the use of electronic examination in a Nigerian University. Mediterranean Journal of Social Sciences, 6(2 S1), 75-80. doi: 10.5901/mjss.2015.v6n2s1p75

Bawarith, R., Basuhail, A., Fattouh, A., \& Gamalel-Din, S. (2017). E-exam cheating detection system. International Journal of Advanced Computer Science and Applications, 8(4), 176181. doi: $10.14569 /$ IJACSA.2017.080425

Benli, İ., \& İSMAİLOVA, R. Use of open-ended questions in measurement and evaluation methods in distance education. International Technology and Education Journal, 2(1), 1-8. Retrieved from http://static.dergipark.org.tr/article-download/2dco/a73a/4b99/5ba24262e92ac.pdf

Böhmer, C., Feldmann, N., \& Ibsen, M. (2018, April). E-exams in engineering education-Online testing of engineering competencies: Experiences and lessons learned. Paper presented at the 2018 IEEE Global Engineering Education Conference (EDUCON), Tenerife, Spain. doi: 10.1109/EDUCON.2018.8363281 
Cabı, E. (2016). Uzaktan eğitimde e-değerlendirme üzerine öğrenci algıları [The perception of students on e-assessment in distance education]. Journal of Higher Education \& Science/Yüksekögretim ve Bilim Dergisi, 6(1), 94-101. doi: 10.5961/jhes.2016.146

Case, C.J., King, D.L., \& Case, J.A. (2019). E-cheating and undergraduate business students: Trends and the role of gender. Journal of Business and Behavioral Sciences, 31(1), 102-113. Retrieved from http://asbbs.org/files/2019/JBBS_31.1_Spring_2019.pdf

Cerimagic, S., \& Hasan, M.R. (2019). Online exam vigilantes at Australian universities: Student academic fraudulence and the role of universities to counteract. Universal Journal of Educational Research, 74), 929-936. doi: 10.13189/ujer.2019.070403

Cluskey, G.R., Jr., Ehlen, C.R., \& Raiborn, M.H. (2011). Thwarting online exam cheating without proctor supervision. Journal of Academic and Business Ethics, 4(1), 1-7. Retrieved from https://gato-docs.its.txstate.edu/jcr:obfbod86-e1df-41f6-a78c$52249218 \mathrm{dcga} /$ Integrity + of + online+exams.pdf

Dermo, J. (2009). e-Assessment and the student learning experience: A survey of student perceptions of e-assessment. British Journal of Educational Technology, 4O(2), 203-214. doi: 10.1111/j.1467-8535.2008.00915.x

D’Souza, K.A., \& Siegfeldt, D.V. (2017). A conceptual framework for detecting cheating in online and take-home exams. Decision Sciences Journal of Innovative Education, 15(4), 370-391. doi: $\underline{10.1111 / \text { dsji.12140 }}$

Elmehdi, H.M., \& Ibrahem, A.M. (2019). Online summative assessment and its impact on students' academic performance, perception and attitude towards online exams: University of Sharjah study case. In M. Mateev \& P. Poutziouris (Eds.), Creative business and social innovations for a sustainable future (pp. 211-218). Cham, Switzerland: Springer. doi: 10.1007/978-3-030$\underline{01662-324}$

Gülbahar, Y. (2017). E-öğrenme [E-learning]. Ankara: Pegem Akademi. doi: $10.14527 / 9786054282098$

Hillier, M. (2014). The very idea of e-Exams: Student (pre) conceptions. In B. Hegarty, J. McDonald, \& S.-K. Lok (Eds.), Rhetoric and Reality: Critical perspectives on educational technology. Proceedings of the Australasian Society for Computers in Learning in Tertiary Education (Ascilite) (pp. 77-88). Retrieved from https://ascilite.org/conferences/dunedin2014/files/fullpapers/91-Hillier.pdf

Ilgaz, H., \& Adanır, G. A. (2020). Providing online exams for online learners: Does it really matter for them?. Education and Information Technologies, 25(2), 1255-1269. doi: 10.1007/s10639019-10020-6

Kirtman, L. (2009). Online versus in-class courses: An examination of differences in learning outcomes. Issues in Teacher Education, 18(2), 103-116. Retrieved from http://www.itejournal.org/issues/fall-2009/12kirtman.pdf 
Kolhar, M., Alameen, A., \& Gharsseldien, Z.M. (2018). An Online Lab Examination Management System (OLEMS) to Avoid Malpractice. Science and Engineering Ethics, 24(4), 1367-1369. doi: $10.1007 / \mathrm{s} 11948-017-9889-\mathrm{Z}$

Krippendorff, K. (2004). Content analysis: An introduction to its methodology (2nd ed.). Thousand Oaks, California: Sage Publications.

Laine, K., Sipilä, E., Anderson, M., \& Sydänheimo, L. (2016, September). Electronic exam in electronics studies. Paper presented at the SEFI Annual Conference 2016: Engineering Education on Top of the World: Industry University Cooperation. Tampere, Finland. Retrieved from http://sefibenvwh.clustero23.hosting.ovh.net/wpcontent/uploads/2017/09/laine-electronic-exam-in-eletronics-studies-9.pdf

Liu, X., Liu, S., Lee, S., \& Magjuka, R.J. (2010). Cultural differences in online learning: International student perceptions. Educational Technology \& Society, 13(3), 177-188. Retrieved from https://www.jstor.org/stable/jeductechsoci.13.3.177

Sarrayrih, M.A., \& Ilyas, M. (2013). Challenges of online exam, performances and problems for online university exam. International Journal of Computer Science Issues (IJCSI), 1O(1), 439-443. Retrieved from http://ijcsi.org/papers/IJCSI-10-1-1-439-443.pdf

Sorensen, E. (2013). Implementation and student perceptions of e-assessment in a Chemical Engineering module. European Journal of Engineering Education, 38(2), 172-185. doi: $\underline{10.1080 / 03043797.2012 .760533}$

Strauss, A., \& Corbin, J. (1990). Basics of qualitative research: Grounded theory procedures and techniques. Newbury Park, CA: Sage Publications.

Timms, M.J. (2017). Assessment of online learning. In A. Marcus-Quinn \& T. Hourigan (Eds.), Handbook on digital learning for K-12 schools (pp. 217-231). Cham, Switzerland: Springer. doi: $10.1007 / 978-3-319-33808-8 \quad 13$

Yllmaz, Ö. (2016). Çevrimiçi sınav görüş anketi [Online examination assessment survey]. e-Kafkas Eğitim Araştırmaları Dergisi, 3(3), 26-33. Retrieved from https://www.researchgate.net/publication/318373752 Cevrimici Sinav Gorus Anketi Onli ne Examination Assessment Survey

Ylioppilastutkintolautakunta. (2017). Digital matriculation examination. Retrieved from https://www.ylioppilastutkinto.fi/en/matriculation-examination/digital-matriculationexamination 